\title{
An Alumni Survey as an Assessment Tool for New Mexico Tech's B.S. Environmental Engineering Curriculum
}

\author{
Randal S. Martin and Clinton P. Richardson \\ Dept. of Mineral \& Environmental Engineering \\ New Mexico Tech \\ Socorro, NM 87801
}

\section{INTRODUCTION}

According to the 1996 report by the Engineering Workforce Commission (EWC) of the American Association of Engineering Societies, Inc. ${ }^{1}$, there are 3376 full-time and 319 part-time undergraduate students enrolled in environmental engineering-related curriculums throughout the United States. Of these, 1911 and 235, respectively, are enrolled in an environmental engineering program at one of 14 colleges and universities accredited by the Accreditation Board for Engineering and Technology $(\mathrm{ABET})^{1,2}$. As can be seen in Table 1, these schools represent a wide geographic area and contain a varying number of students enrolled in environmental engineering curriculums. Additionally, Table 1 shows other schools which offer similar or related programs accredited under ABET's Environmental Engineering Group (e.g. Civil \& Environmental Engineering).

The Department of Mineral and Environmental Engineering at the New Mexico Institute of Mining and Technology (New Mexico Tech) in Socorro, New Mexico has awarded Bachelor of Science degrees in Environmental Engineering since 1970 and became officially ABET-accredited in 1993. As a part of the periodic reviews mandated by ABET, as well as by the North Central Association of Colleges and Schools, the Environmental Engineering Program at New Mexico Tech developed an assessment survey to evaluate alumni's opinions concerning the program's curriculum and its preparation for their subsequent careers, whether professional employment or graduate school.

\section{BACKGROUND AND SURVEY INFORMATION}

The required course work leading to a Bachelor of Science degree in Environmental Engineering at New Mexico Tech (NMT) includes 59 credits of college-wide basic requirements, 55 credits of supporting engineering and science classes, and 24 credits of core environmental engineering classes. A total of 138 credits is divided over 52 classes, inclusive of laboratory classes. Figure 1 shows NMT's most recent (1997-1998) undergraduate environmental engineering curriculum ${ }^{3}$. Although the environmental engineering curriculum at New Mexico Tech has continued to evolve over the past decade, the emphasis and the core courses have remained essentially the same. The most significant deletions within the last few years have been the removal of Fluid and Thermal Systems, Transport Processes, Finite Element Analysis, and Case Studies in Industrial Environmental Problems. Recent additions to the environmental engineering curriculum have included Elementary Fluid Mechanics, Heat and Mass Transfer, Organic Chemistry I, and Environmental Law and Regulations. 
The survey was separated into two main sections: (1) Employment Information and (2) Curriculum Survey. Additionally, although the forms were intended to be anonymous, information was also solicited on gender and year of graduation. The Employment Information section of the survey consisted of questions regarding years of employment within an environmentally-related field, sector of employment (regulatory, industry, consulting, etc.), salary range, job titles and promotions, responsibilities, supervisory duties, and so on. The Curriculum Survey portion of the questionnaire asked for information on which of NMT's courses were most and least useful, any additional courses which should be added to the program, pursuit of graduate degrees, and departmental, as well as college-wide, faculty competence and availability. Figure 2 shows the actual questions included on the survey form.

The survey was E-mailed or sent via surface mail, including a self-addressed, stamped envelope, to all locatable alumni who had graduated since the 1987-1988 school year. Although the program has been in existence since 1970, it was felt this time period most adequately represented the current curriculum, and would, therefore, elicit the most relevant responses. During this period 108 Bachelor of Science degree in Environmental Engineering were awarded, with a gender split of $70.4 \%$ male and $29.6 \%$ female. The survey and an introductory form letter were sent to the 96 alumni for whom addresses (street or E-mail) could be established through personal contacts, known employers, or NMT's alumni office.

\section{RESULTS AND DISCUSSION}

The surveys were mailed out in late September, and responses came in over the following several months. Four of the surveys were returned as undeliverable. In total, 40 responses (42\%) were received, with $73 \%$ being received from male alumni and $27 \%$ being received from female alumni. These percentages are very similar to the overall graduation percentages previously discussed.

\section{Employment Information}

Several interesting issues were noted from the compiled Employment Information portion of the survey. Eighty percent of the responding graduates found initial employment within the environmental engineering field, and $78 \%$ of the original respondents remain employed within the field. Sixty-four percent $(64.1 \%)$ of the total responding graduates have sought or obtained some type of professional certification. A slightly higher percentage $(72.4 \%)$ of those within the environmental engineering field sought or obtained certification. The bulk of the registrations consisted of Fundamentals of Engineering (FE, formerly EIT) or Professional Engineering (PE) certifications.

Figure 3 shows the division of the environmentally-employed graduates among the regulatory, industrial, consulting, and other (e.g. civilian military employees, graduate school) employment sectors. As can be seen, consultant companies employ the largest portion (33\%) of the graduates, industrial and regulatory sectors account for approximately equal percentages $(27 \%$ and $23 \%$, respectively), and the "other" category accounts for the remaining 17\%. Figure 3 also shows the divisions among the employment sectors as a function of gender. It is interesting to note the consulting and regulatory sectors were the strongest employers (43\% each) for the female 
graduates. The industrial sector hired only $14 \%$ of the responding female graduates and the "other" sector hired none. In contrast, the industrial and consulting sectors were the dominant employers (30\% each) for the male graduates, with only marginally smaller percentages in the remaining two categories.

The starting salaries, corrected to 1997 dollars, for all of the B.S. Environmental Engineering graduates averaged approximately $\$ 32,300$. An apparent gender basis was noted, with female graduates receiving average starting salaries of $\$ 30,600$ and male graduates receiving average starting salaries of $\$ 32,800$. However, it should also be noted that the starting salary ranges for each of the sexes were dramatically different. Starting salaries for females and males ranged from $\$ 27,000$ to $\$ 35,600$ and $\$ 17,300$ to $\$ 59,500$, respectively. According to the collected data, the largest gender inequity occurred within the industrial employment sector. However, these data must be interpreted with caution as no information was collected on the number of job offers or graduate preferences for particular employment sectors. As shown in Figure 4, the average starting salary within the industrial sector was $\$ 30,000$ for females and $\$ 38,300$ for males. The regulatory sector showed a smaller, positive female basis $(\$ 31,400$ vs. $\$ 28,600)$. The consulting sector hired females and males at essentially the same rate $(\$ 30,000$ vs. 30,400). Insufficient data exist to comment on inequities within the "other" sector.

\section{Curriculum Survey}

Table 2 shows the compiled data indicating the classes which the responding alumni found most and least useful as applied to their career paths. Additionally, suggested course additions are also shown. Data were included in Table 2 only when at least two responses were recorded for a given class. It should further be noted that individual responses were not limited to one class per category, and, in fact, most respondents listed several courses in each.

As perhaps may be expected, the required core environmental engineering classes, with the exception Soil Mechanics and Senior Design Thesis, led the list of most useful courses. Groundwater Hydrology, taught through NMT's Earth and Environmental Science Department, and Wastewater Treatment Process Design equally received favorable responses from $20 \%$ of the alumni, second only to Air Pollution Engineering I \& II (32.5\%). Environmental Law and Regulations, Solid \& Hazardous Waste Engineering, and Water Treatment Process Design were all deemed about equally useful. This seemingly indicates that NMT's undergraduate program adequately addresses the wide range of job assignments encountered under the environmental engineering umbrella. Interestingly, several supporting classes appeared among the most useful including Technical Writing, Chemistry, Transport Processes, Fluid Mechanics, Environmental Microbiology, and General Biology.

Instrumentation, Measurement, and Process Control topped the list (17.5\%) as the class found to be least useful be the responding graduates (see Table 2). This course was originally taught under the Department of Electrical Engineering, and gradually evolved into a course dealing with time and frequency domains. In 1994 and 1996, the class was modified under the guidance of the Environmental Engineering Program and the Engineering Science Group to be a practical survey course covering the basic components of instrumentation, measurement, and process control systems common to the field of engineering. At present, approximately 1.2 credit hours of the 
course are designed to deal with the theory of process control, 0.8 credit hours are designated for coverage of common measurements and instrumentation, and 1.0 hour is assigned to practical laboratory exercises. The unfavorable responses include time periods covering both the previous and the current version of the class. The surveyed data suggest a revisitation of the course content should be implemented.

Cell Biology and Physical Chemistry, although they were also near the top of the least useful list (see Table 2), are not likely to be modified as they are both prerequisites for subsequently required classes. Finite Element Analysis, which was also viewed as unfavorable by a number of graduates, has been dropped as a requirement from the Environmental Engineering curriculum as of the 1996-1997 school year and replaced with Organic Chemistry I.

Suggestions for additional courses were led by requests for a separate class dealing with environmental law. All of these responses were from 1995 and earlier alumni, who graduated before NMT's addition of Environmental Law and Regulations as a required class. Other suggestions included course work in general areas of civil engineering, computer design/modeling, and business and management, and more discipline-specific areas such as site assessment, HAZWOPER training, and geology.

Approximately 33\% of the respondents have obtained or are in the process of obtaining graduate degrees. Most of the advanced degrees are Masters of Science in Environmental Engineering, but some graduates have pursued advanced degrees in other disciplines such as mechanical engineering, chemical engineering, nuclear engineering, environmental management, etc. With one exception, the continuing graduates felt the undergraduate curriculum at NMT prepared them well for graduate school. Responses included comments such as "good study skills", "everything (in graduate school) is rehash", "feel ahead of the rest of the students", "NMT harder -- learned more", and "prepared for workload/challenges". The single response which indicated NMT did not prepare the student well enough for graduate school gave no supporting comments. Overall, the alumni were pleased with their experience at New Mexico Tech. On a scale of one to five, with one being very poor and five being excellent, the responding graduates rated their overall educational experience as an average of $4.28 \pm 0.72$ (the uncertainty represents one standard deviation). Departmental faculty competence and availability were rated at $4.38 \pm 0.88$ and 4.49 \pm 0.72 , respectively. College-wide faculty competence averaged 4.03 \pm 0.71 .

\section{ACKNOWLEDGMENTS}

The authors would like to acknowledge the assistance of Ms. Lisa Garcia of NMT's Department Research and Economic Development, Ms. Joanna Lucero and Ms. Jennifer Knowlton of NMT's Department of Mineral \& Environmental Engineering for their help in the mailing, compilation, and analysis of the survey data. Extreme thanks and unending gratitude are also extended to NMT's Environmental Engineering alumni, for without their pre-graduation presence and their post-graduation cooperation, this work would not have been possible. 


\section{REFERENCES}

[1] Engineering Workforce Commission (1997), Engineering and Technology Enrollments: Fall 1996, American Association of Engineering Societies, Inc., Washington, D.C.

[2] Accreditation Board for Engineering and Technology (1996), 1996 Accreditation Yearbook: For Accreditation Cycle Ended July 1996, Engineering Accreditation Commission, Technology Accreditation Commission, Related Accreditation Commission.

[3] New Mexico Tech (1997), Science and Engineering 1997-1998 Catalog, New Mexico Institute of Mining and Technology, Socorro, NM 87801

\section{BIOGRAPHICAL INFORMATION}

RANDAL S. MARTIN, Associate Professor of Environmental Engineering Dr. Martin received his Ph.D. in Civil Engineering from Washington State University in 1992. At New Mexico Tech, he has had prime responsibility for air pollution-related courses at both the undergraduate and graduate level. Dr. Martin's research interests include biogenic non-methane and oxygenated hydrocarbons, atmospheric modeling and photochemistry, and catalytic air pollutant control.

CLINTON P. RICHARDSON, Department Chair, Associate Professor of Environmental Engineering. Dr. Richardson received his Ph.D. in Civil Engineering from the University of Kansas in 1987. Dr. Richardson's teaching interests include water and wastewater treatment, solid \& hazardous waste engineering, geotechnical waste containment, and a wide variety of general engineering courses. His research interests include biological wastewater treatment, groundwater remediation, and geotechnical waste containment. 
Table 1. ABET-accredited environmental engineering schools and undergraduate enrollments ${ }^{1,2}$.

\begin{tabular}{|c|c|}
\hline Environmental Engineering & Enrollment (Fall 1996) \\
\hline California Polytechnic State University & 279 \\
\hline University of California - Riverside & 45 \\
\hline University of Central Florida & 246 \\
\hline University of Florida & 343 \\
\hline Michigan Technical University & 331 \\
\hline Montana Tech of the University of Montana & 244 \\
\hline New Mexico Institute of Mining and Technology & 131 \\
\hline North Carolina State University - Raleigh & 148 \\
\hline Northern Arizona University & 115 \\
\hline Northwestern University & 80 \\
\hline Rensselaer Polytechnic Institute & 70 \\
\hline Stevens Institute of Technology & 39 \\
\hline Syracuse University & 62 \\
\hline Utah State University & 136 \\
\hline \multicolumn{2}{|l|}{ Civil and Environmental Engineering } \\
\hline University of Michigan & 255 \\
\hline University of Pittsburgh & unavailable \\
\hline Tufts University & 93 \\
\hline Youngstown State University & 98 \\
\hline \multicolumn{2}{|l|}{ Civil Eng. with Environmental Eng. Option } \\
\hline Ohio State University & unavailable \\
\hline \multicolumn{2}{|l|}{ Environmental Engineering Science } \\
\hline Massachusetts Institute of Technology & 72 \\
\hline \multicolumn{2}{|l|}{ Environmental Resources Engineering } \\
\hline Humbolt State University & 375 \\
\hline
\end{tabular}


Table 2. Alumni survey results for which there was more than one response of the most useful, least useful, and suggested additional courses concerning NMT's environmental engineering undergraduate curriculum.

\begin{tabular}{|c|c|c|c|c|c|}
\hline $\begin{array}{l}\text { Most Useful } \\
\text { Courses }\end{array}$ & $\begin{array}{c}\% \text { of } \\
\text { Responses }\end{array}$ & $\begin{array}{c}\text { Least Useful } \\
\text { Courses }\end{array}$ & $\begin{array}{c}\% \text { of } \\
\text { Responses }\end{array}$ & $\begin{array}{l}\text { Suggested } \\
\text { Additions }\end{array}$ & $\begin{array}{c}\% \text { of } \\
\text { Responses }\end{array}$ \\
\hline Air Pollution Engineering & 32.5 & Instr. \& Process Control & 17.5 & Law & 20.0 \\
\hline Groundwater Hydrology & 20.0 & Cell Biology & 10.0 & Management & 7.5 \\
\hline Wastewater Treatment & 20.0 & Physical Chemistry & 10.0 & Civil Engineering Classes & 5.0 \\
\hline Environmental Law & 15.0 & Finite Element Analysis & 7.5 & Business & 5.0 \\
\hline Hazardous \& Solid Waste & 15.0 & Humanities & 5.0 & Site Assessment & 5.0 \\
\hline Water Treatment & 12.5 & Groundwater Hydrology & 5.0 & HAZWOPER Short Course & 5.0 \\
\hline All Env. Eng. Classes & 12.5 & Electrical Engineering & 5.0 & Geology & 5.0 \\
\hline General Engineering & 10.0 & History & 5.0 & Computer Design/Modeling & 5.0 \\
\hline Technical Writing & 10.0 & Quantitative Analysis & 5.0 & & \\
\hline Chemistry & 10.0 & Engineering Economics & 5.0 & & \\
\hline Air Pollution Sampling Lab & 10.0 & & & & \\
\hline Transport Process & 7.5 & & & & \\
\hline Water \& Wastewater Lab & 7.5 & & & & \\
\hline Env. Microbiology & 5.0 & & & & \\
\hline Fluid Mechanics & 5.0 & & & & \\
\hline Biology & 5.0 & & & & \\
\hline
\end{tabular}


Figure 1. New Mexico Tech's 1997-1998 environmental engineering curriculum³

\section{Total Degree Requirements $=138$ credits}

Basic Degree Requirements (59)

Calculus I (4)

Calculus II (4)

Physics I and lab (5)

Physics II and lab (5)
Chemistry I and lab (4)

Chemistry II and lab (4)

Biology I and lab (4)

Intro to Engr I (2)

Intro to Engr II (3)
English I (3)

English II (3)

Humanities (6)

Social Sciences (9)

Hum./S.S. elect (3)

\section{Required Supporting Courses (55)}

Technical Writing (3)

Calculus III (4)

Diff. Equations (3)

Applied Statistics (3)

Cell Biology (3)

Env. Microbiology (3)

Groundwater Hyd. (3)
Quant. Analysis (3)

Physical Chemistry (3)

Organic Chemistry I (3)

Fluid Mechanics (3)

Statics (3)

Mech. of Materials (3)
Eng. Economics (3)

Electrical Eng. (3)

Thermodynamics (3)

Heat \& Mass (3)

Process Control \&

Meas. with lab (3)

\section{Environmental Engineering Core Courses (24)}

Introduction to Env. Eng. (3)

Env. Laws \& Regulations (2)

Water Treatment Process Design (2)

Wastewater Treatment Process Design (2)

Water \& Wastewater Laboratory (1)

Senior Design Thesis (3)
Air Pollution Eng. I (2)

Air Pollution Eng. II (2)

Air Pollution Sampling (1)

Soil Mechanics and lab (2)

Solid \& Haz. Waste Eng. (4) 
Figure 2. Employment information and curriculum survey questions.

\section{General Information}

Year of Graduation?

Gender (male or female)?

\section{Employment Information}

Are you currently employed in the environmental field (yes or no)?

Approximately how long have you been employed within the field?

How many employers within the field have you worked for?

What is your current salary range?

What was your starting salary, and in what year?

Would you describe your employer as Regulatory, Industry, Consulting, or other?

Please list your current title and responsibilities.

What were your previous job titles, if any?

Have you obtained any professional registration (EIT, FE, PE, QEP, etc.)? If so, what, when, and where?

Please comment on your current supervisory responsibilities (e.g. how many people, what category of employees, etc.).

\section{Curriculum Survey}

Which courses at NMT were most useful?

Which courses at NMT were least useful?

Are there any additional types of courses which you feel would be beneficial to the students currently enrolled in the environmental engineering program?

Since graduation have you pursued or obtained an advanced degree?

If so, what, where, and when?

Did NMT adequately prepare you for graduate school? Why or why not?

Following a 1 to 5 scale $(1=$ very poor, $5=$ excellent $)$, rate the following items:

Departmental faculty availability

Departmental faculty competence

College-wide faculty competence

Overall educational experience at NMT 


\section{Total Hires $(n=31)$}

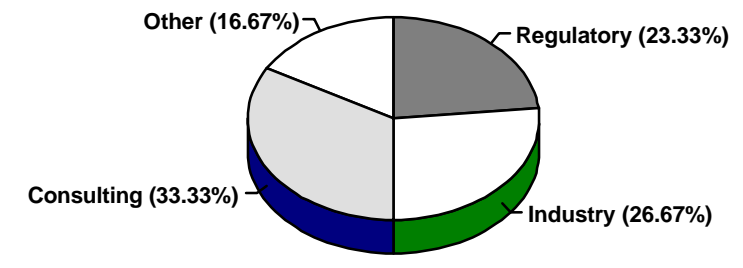

Females Hires $(n=9)$

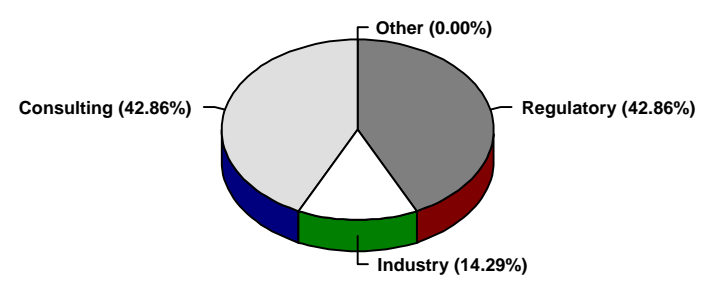

Male Hires $(\mathbf{n}=22)$

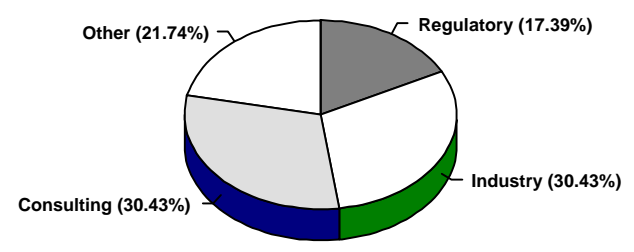

Figure 3. Employment sector and gender distributions of starting positions obtained by NMT's B.S. Environmental Engineers. 


\section{Average Starting Salaries 1997 Dollars}

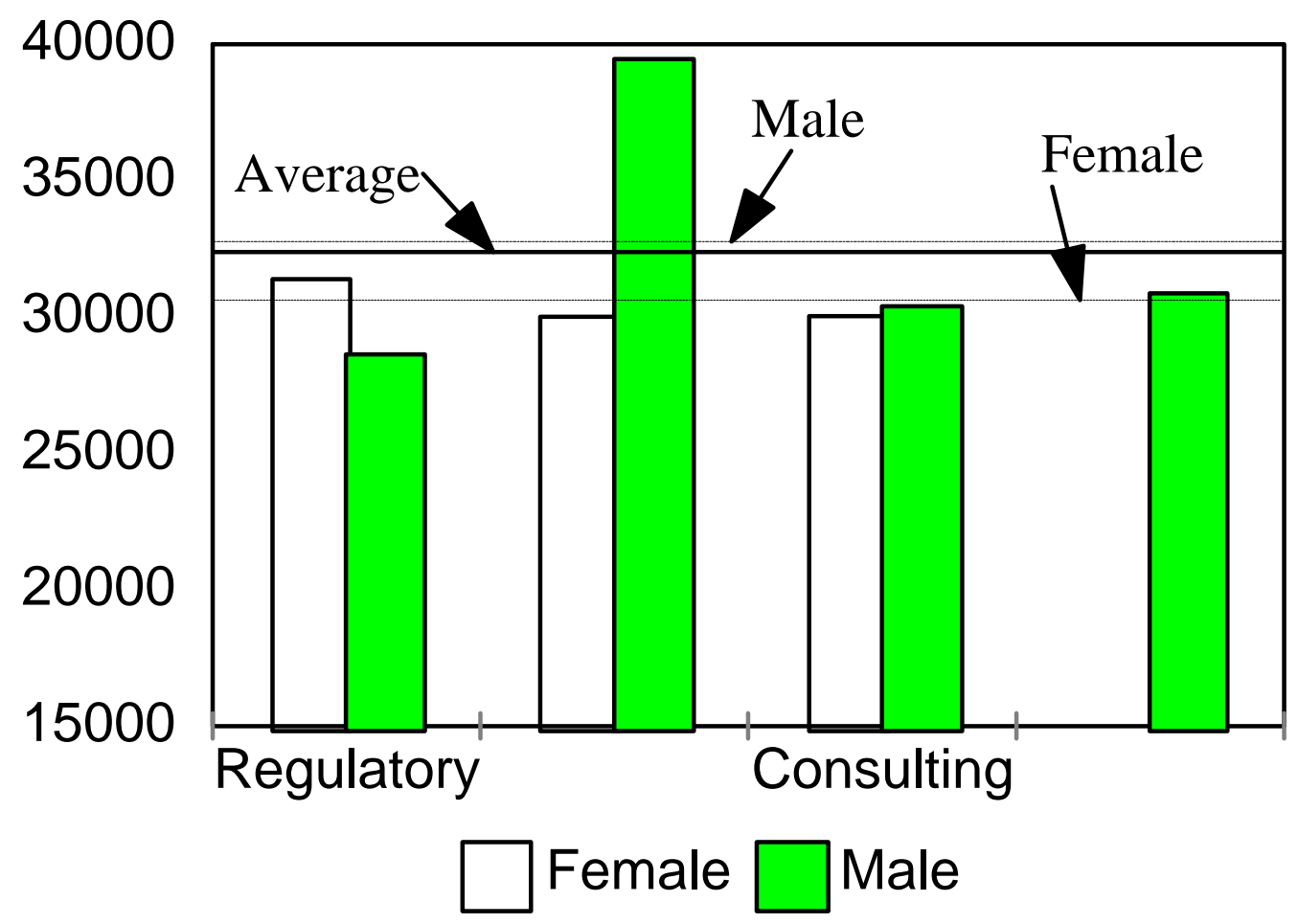

Figure 4. Gender and employment distributions of starting salaries obtained by NMT's B.S. Environmental Engineers. 